\title{
CONFLICTING DISCOURSES OF 'DEMOCRACY' AND 'EQUALITY': A DISCOURSE ANALYSIS OF THE LANGUAGE OF PRO- AND ANTI-LGBTQ+ INCLUSION IN THE RELATIONSHIPS AND SEX EDUCATION GUIDANCE FOR SCHOOLS IN
} ENGLAND

\author{
DISCURSOS CONFLITANTES SOBRE 'DEMOCRACIA' \\ E 'IGUALDADE': UMA ANÁLISE DO DISCURSO DA \\ LINGUAGEM DA INCLUSÃO PRÓ E ANTI-LGBTQ+ NA \\ ORIENTAÇÃO DE RELAÇÕES E EDUCAÇÃO SEXUAL PARA \\ ESCOLAS NA INGLATERRA
}

Helen Sauntson *

\begin{abstract}
New statutory Relationships and Sex Education (RSE) guidance for schools in England was published in 2019. One of the major revisions since the preceding version has been the new inclusion of LGBTQ+ identities and relationships. Some groups in the UK have recently protested against this inclusion of positive teaching about LGBTQ+ identities and relationships, suggesting that, although there is overwhelming support for the new guidance, there are still groups in society who are opposed to democratic teaching about this dimension of equality. Focusing on publicly-available video recordings of the protests, this article firstly critically analyses the key discursive strategies deployed by the anti-LGBTQ+ protest groups to produce discrimination and denial. I then compare the language used by the protest groups against the language used by other UK groups who support and continue to campaign for LGBTQ+ inclusion in RSE. Positive discourse analysis, as a progressive dimension of critical discourse analysis, is used to examine how the language used by these groups functions to resist the discriminatory discourse used by the anti-LGBTQ+ groups analysed in the first part of the article. Analysis of the discourse used by the two sets of groups reveals conflicting discourses around what is perceived to constitute 'democracy' and 'equality' in the context of LGBTQ+ inclusion and schools, suggesting that these are fragile concepts in the current British political climate.
\end{abstract}

\footnotetext{
* York St John University, York, United Kingdom, UK. h.sauntson@yorksj.ac.uk

Orcid: https://orcid.org/0000-0002-0373-1242
} 
Keywords: relationships and sex education; LGBT + inclusion; critical discourse analysis; positive discourse analysis.

\section{RESUMO}

A nova orientação estatutária de Relações e Educação Sexual (RSE) para escolas na Inglaterra foi publicada em 2019. Uma das principais revisões desde a versão anterior foi a nova inclusão de identidades e relacionamentos LGBTQ+. Alguns grupos no Reino Unido protestaram recentemente contra essa inclusão de ensinamentos positivos sobre identidades e relacionamentos LGBTQ+, sugerindo que, embora haja um apoio esmagador para a nova orientação, ainda há grupos na sociedade que se opõem ao ensino democrático sobre essa dimensão da igualdade. Com foco nas gravações de vídeo disponíveis publicamente dos protestos, este artigo analisa em primeiro lugar criticamente as principais estratégias discursivas implantadas pelos grupos de protesto anti-LGBTQ+ para produzir discriminação e negação. Então comparo a linguagem usada pelos grupos de protesto contra a linguagem usada por outros grupos britânicos que apoiam e continuam a fazer campanha pela inclusão LGBTQ + na RSE. A análise positiva do discurso, como dimensão progressiva da análise do discurso crítico, é utilizada para examinar como funciona a linguagem utilizada por esses grupos para resistir ao discurso discriminatório utilizado pelos grupos anti-LGBTQ+ analisados na primeira parte do artigo. A análise do discurso utilizado pelos dois grupos revela discursos conflitantes em torno do que se percebe constituir "democracia" e "igualdade" no contexto da inclusão LGBTQ+ e das escolas, sugerindo que estes são conceitos frágeis no atual clima político britânico.

Palavras-chave: relacionamentos e educação sexual; inclusão LGBT+; análise crítica do discurso; análise positiva do discurso.

\section{INTRODUCTION}

Amended guidance for Relationships and Sex Education (henceforth RSE) for schools in England ${ }^{1}$ was published in 2019 after a two-year review period and implemented in schools in September 2020. The RSE guidance was revised following heavy criticism of the preceding version, as well as a need for RSE to incorporate relevant UK legal changes such as the Same-Sex Marriage Act (2013) and the Equality Act $(2010)^{2}$. One of the major revisions since the preceding version has been the inclusion of LGBTQ+ identities and relationships. The current guidance now contains two paragraphs referencing the teaching of same-sex relationships and LGBT+ identities:

36. In teaching Relationships Education and RSE, schools should ensure that the needs of all pupils are appropriately met, and that all pupils understand the importance of equality and respect. Schools must ensure that they comply with the relevant provisions of the Equality

1. RSE provision is devolved in the UK.

2. See Author1 (2018) for more information about the historical development of Relationships and Sex Education in the UK. 
Act 2010, (please see The Equality Act 2010 and schools: Departmental advice), under which sexual orientation and gender reassignment are amongst the protected characteristics.

37. Schools should ensure that all of their teaching is sensitive and age appropriate in approach and content. At the point at which schools consider it appropriate to teach their pupils about LGBT, they should ensure that this content is fully integrated into their programmes of study for this area of the curriculum rather than delivered as a standalone unit or lesson. Schools are free to determine how they do this, and we expect all pupils to have been taught LGBT content at a timely point as part of this area of the curriculum.

https://assets.publishing.service.gov.uk/government/uploads/system/uploads/attachment data/file/805781/Relationships_Education__Relationships_and_Sex_Education_RSE__ and_Health_Education.pdf

Some groups have recently mobilised against this inclusion of positive teaching about LGBTQ + identities and relationships by, for example, holding public protests outside schools. In May 2019, a number of high-profile protests against the teaching of LGBT+ identities and relationships outside Birmingham primary schools and, more specifically, the No Outsiders equality programme for schools which is designed to teach children about differences in religions, families and relationships in a positive and accepting way ${ }^{3}$. Protesters primarily argued that the subject matter of the programme contradicted the Islamic faith (although there were also a small number of protesters from other faith groups) and argued that primary school children were too young to be made aware of same-sex relationships. The programme was suspended following the protests. Although protests only took place in Birmingham, the National Association of Head Teachers (NAHT) reported that up to 70 schools in England had encountered varying degrees of resistance to the programme from parents.

These protests suggest that although there is much support for the new guidance, there are still groups in society who are opposed to democratic teaching about this dimension of equality. And their voices are being heard in ways that could potentially 're-silence' (AUTHOR2 and BORBA, in press) the opening up of positive teaching about sexual diversity.

This article firstly analyses the key discursive strategies deployed by the anti-LGBTQ+ protest groups (henceforth the anti-inclusion groups) to distort progressive views of gender and sexuality within the UK school context. I conduct a discourse analysis of talk in some of the publicly-available video recordings of the protests, as well as associated media reporting of the protests. The discursive practices are analysed using Van Dijk's (1992) critical discourse analysis framework for analysing discriminatory discourse and denial strategies. I then compare the language used by the anti-inclusion groups against the language used by other UK

3.See https://no-outsiders.com/ for further information. 
groups who support and continue to campaign for LGBTQ+ inclusion in RSE (henceforth the pro-inclusion groups). The groups focused on are Schools Out and Imaan LGBTQ.

Established in 1974 as The Gay Teachers Association, Schools OUT UK is an education charity focused on making schools safe for LGBT + communities. The charity engages in research, debate and curriculum development relating to LGBT+ people and issues. Schools Out plays a leading role in the UK in campaigning on LGBT + issues as they affect education (and those working and studying within it) and in raising awareness of issues relating to gender and sexuality in education. The charity works closely with the UK government and is often asked to evaluate educational initiatives, bills and directives before they are presented to Parliament.

Founded in 1999 in London, Imaan LGBTQ is the leading Muslim LGBTQ charity in both the UK and Europe. The charity provides a peer support group for LGBTQ Muslims and aims to help reconcile religious faith with sexuality and gender identity. The group is predominantly a highly active online community (with an online newsletter, forum, website and social media platforms) but also has a presence at events such as Pride.

Positive discourse analysis (e.g. BARTLETT, 2012; HUGHES, 2018; MARTIN, 2004), as a progressive dimension of critical discourse analysis, is used to examine how the language used by these groups functions to resist the discriminatory discourse used by the anti-LGBTQ+ groups analysed in the first part of the article.

The analysis shows that both the anti- and pro-inclusion groups claim that the other group is being discriminatory and undemocratic. This suggests that the very concepts of 'democracy' and 'equality' are themselves inherently fragile, unstable and open to contestation.

\section{DATA AND ANALYTICAL FRAMEWORKS}

The first part of this article focuses on an analysis of the discourse of the anti-inclusion groups in order to investigate how their arguments are constructed and bolstered and, significantly, how they are able to express discriminatory views whilst 'saving face' through a range of discursive denial strategies. Whilst the views expressed by the anti-inclusion groups received much support, they were also widely refuted and opposed. The second part of the analysis therefore focuses on the counter-arguments produced by pro-inclusion groups as a means of challenging the views of the anti-inclusion groups and framing them as homophobic. To this 
end, positive discourse analysis is used to analyse the language used in the counterarguments as a means of exploring how resistance to homophobia is achieved in these texts.

The first data-set comprises 15 transcribed videos taken from YouTube (https://www.youtube.com/). The videos vary in length and were selected as they were the first fifteen unscripted videos to appear on the same date (12 December 2019) when 'Birmingham school protests' was used as a search term on YouTube. The number of views $(1,241,515$ in total) provides evidence of the high public circulation of the videos in this data-set. The selection of the first 15 videos also minimises the extent to which the data was pre-selected by the researcher. And after the first 15, the videos started to become less relevant to the topic under investigation. The second data-set focuses on text taken from the websites of the two most prominent pro-LGBT+ inclusion groups in the UK who publicly challenged the views expressed by the anti-inclusion groups - Schools Out (http://www.schoolsout.org.uk/) and Imaan LGBTQ (https://imaanlondon.wordpress.com/). There were no videos posted by these groups on YouTube so directly comparable data could not be found. However, the groups directly challenge and resist homophobic discourse in relation to school settings on their websites (including in RSE) so the website texts provide a good source of data for investigating resistant discourse in this study. Data-set 1 is analysed using elements of critical discourse analysis in order to uncover the ideologies of inequality inscribed in the language use of the anti-inclusion groups. Specifically, analysis of this data-set focuses on the use of denials of homophobia by the anti-inclusions groups - a defence used frequently in order to facilitate the public expression of homophobic views in a context in which this form of discrimination is illegal. Data-set 2, with more of a focus on resistance rather than inequality and power, is analysed using selective elements of positive discourse analysis. These analytical frameworks and associated literature are described in more detail below.

\subsection{Critical discourse analysis (CDA)}

CDA is concerned with social injustice, power struggles and in/equalities and with examining the role that discourse plays in constructing, reifying and contesting these issues. This makes it a particularly relevant approach for investigating attitudes towards sexuality in relation to language. Flowerdew (2008) explains that the main aim of CDA is to uncover hidden assumptions with a view to subsequently debunking their claims to authority. CDA thus has a specific agenda in bringing about social change. Because it is interested in power relations, CDA typically 
examines specific discursive situations where dominance and inequality are to the fore.

Various types of linguistic analysis are used within CDA, and there are numerous formal linguistic features which can be focused on in applying CDA, such as (but not limited to): lexical items; metaphors; evaluative language (e.g. semantic fields and adjectives); intertextual references; grammatical and syntactic structures. Van Dijk (2001) provides a lengthy list of textual features which can be examined using CDA - this list includes local semantic moves (such as disclaimers and denials). It is these kinds of local semantic moves that are the units of analysis for the CDA in this article.

Given the wide-ranging possibilities for applying CDA and the resistance to espousing a 'monolithic' approach (as argued by Wodak and Meyer, 2009), some authors have devised more focused frameworks for analysing specific issues such as prejudice and discriminatory language. One such framework is used in this article to analyse the data-sets - that of Van Dijk (1992) who focuses on expressions of racist and anti-immigrant sentiment to devise his categorisation system. Van Dijk (1992, p. 87) observes that:

Ethnic and racial prejudices are prominently acquired and shared [...] through everyday conversation and institutional text and talk. Such discourse serves to express, legitimate or indeed to conceal or deny such negative ethnic attitudes.

I argue that these same principles of CDA can be applied to analysing the language of homophobia. Based on van Dijk's definition above, I therefore formulate the following proposition:

Gender-and sexuality-based prejudices are prominently acquired and shared ... througb everyday conversation and institutional text and talk. Such discourse serves to express, legitimate or indeed to conceal or deny such negative attitudes.

Jackson (2014) and Marlow (2015) also note that racist discourse often contains expressions of the inherent superiority of the speaker's own racial group along with explicit denials of racism. Again, we see these same characteristics in the data analysed for this article - but in relation to expressions of homophobia rather than racism. The anti-inclusion groups use discourse which contains expressions of the inherent superiority of heterosexuality.

Van Dijk (1992) devises a number of discursive categories for analysing types of linguistic denial. Van Dijk focuses on the denial of racism but the categories can equally be applied to denials of homophobia as they are in this article. The benefit of using van Dijk's categories is that it provides a detailed and nuanced taxonomy 
for examining discursive denials which, he argues, are a key rhetorical device in the circulation of discriminatory ideologies. In his focus on racist discourse, van Dijk observes that denial is one of the most crucial properties of contemporary racism. In the data examined in this article, there were similarly many instances in which the speakers denied being homophobic but their homophobic attitudes were concurrently betrayed by the use of other discursive strategies of prejudice. Van Dijk argues that discursive denials are important for creating positive ingroup presentation in a context where blatant racism is considered socially unacceptable and that 'language users who say negative things about minorities are well aware of the fact that they may be understood as breaking the social norm of tolerance or acceptance' (VAN DIJK, 1992, p. 89). These influential 'face-saving' practices are also seen in expressions of homophobia as will be illustrated in the data analysis sections of this article. The categories included in Van Dijk's framework are listed and described in section 3 along with illustrative examples from the data-set.

\subsection{Positive discourse analysis}

What Martin $(1999 ; 2004)$ terms positive discourse analysis (PDA) emerged as a response to some limitations of CDA identified in the preceding years. Luke (2002) identifies a need for CDA to move beyond an exclusive focus on the critique of oppression, injustice, ideology and power towards incorporating an analysis of other kinds of text which may be characterised more by productive, communal and egalitarian uses of power. Luke (2002, p. 105) argues that CDA 'must be able to demonstrate what "should be" as well as what is problematic with text and discourse in the world.' In response to such comments, Martin develops and describes the approach of PDA as 'a positive style of discourse analysis that focuses on hope and change, by way of complementing the deconstructive exposé associated with critical discourse analysis' (MARTIN, 1999, p. 29). Martin proposes that PDA is used as an extended and complementary method alongside CDA rather than as an alternative to it. Whereas CDA is implicated in identifying oppression, exploitation and unequal and often abusive power relationships, Stibbe (2017) points out that PDA complements this by focusing instead on the positive uses of language that can provide an alternative to the damaging discourses identified in CDA.

The emancipatory focus of PDA, with its emphasis on liberation and agency, has been developed by writers such as Bartlett (2012), Flowerdew (2008), Hughes (2018), Macgilchrist (2007), Martin (1999; 2004), Nartey and Ernanda (2020), Rogers and Mosley Wetzel (2013) and Stibbe (2017). Bartlett (2012) and Nartey and Ernanda (2020) note that, in emphasizing discourses of resistance, PDA research 
has illustrated how discourse can be used to advance the cause of marginalized or oppressed groups as well as promote the shared interests and collective aims of a social group. In such studies, a common feature is a commitment to a discourse of social change which is deployed by social actors to reconstruct their oppressive circumstances and formulate a progressive discourse. In this research, the marginalized groups who attempt to formulate progressive discourses are LGBT+ communities and those who advocate for them. By privileging resistance as its object of analysis, PDA serves its emancipatory aim by highlighting and examining discourses that attempt to oppose injustices such as discrimination and exclusion (HUGHES, 2018). Resistance within PDA is not only viewed as a response to injustice, but also as a social action capable of instigating progressive social change.

Some authors caution that PDA could be accused of setting up a false opposition with CDA, arguing that the term 'critical' already incorporates both positive and negative, deconstruction and construction. Macgilchrist (2007) points out that CDA already incorporates a positive element, in arguing for a better world. Despite this, Macgilchrist goes on to argue that CDA methodologies often do position resistance as secondary to oppression. Definitions often fail to explicitly mention resistance as an object of analysis, thereby representing the practice of doing CDA in a way that legitimizes negative critique and casts positive critique outside the scope of mainstream CDA. Macgilchrist goes on to assert that:

PDA privileges resistance as its object of analysis. While all CDS is resistant in the sense of opposing injustice, PDA is doubly resistant in that it serves this emancipatory aim by amplifying and investigating discourses that look to redress injustices like exclusion and discrimination. (MACGILCHRIST, 2007, p. 199)

In terms of its application to texts, Stibbe (2017) and Rogers and Mosley Wetzel (2013) observe that PDA is not a new set of methods from CDA but rather a framework that enables researchers to shift their analytic focus to instances of hope, liberation, justice, and agency. In other words, the emphasis in the analysis shifts towards describing "what texts "do well" and "get right" in our eyes.' (MACGILCHRIST, 2007, p. 74) Similarly, Hughes (2018) argues that, while CDA emphasises oppression and resistance, PDA's primary focus is on resistance in its application. Stibbe (2017) points out that, methodologically, this means that CDA tends to focus on identifying typical patterns of language use which are present across numbers of texts - the data-sets for use in CDA can be fairly large as the dominant discourse patterns identified often form the dominant discourses in society. PDA, on the other hand, is better suited to being used to provide detailed analyses of smaller numbers of texts to reveal positive features - these texts may be 
produced by marginalised groups as a way of expressing resistance to the dominant discourses identified through CDA. Stibbe argues that, because of the focus on resistance in PDA, there is no need to establish how widespread the discourse features identified are. For this reason, the pro-inclusion data-set in this project (analysed in section 4) is smaller than the anti-inclusion data-set.

In light of these developments in CDA and PDA, I draw on some of the analytical tools of CDA to analyse how discourse functions to oppress and discriminate against marginalised LGBT + communities in the first data-set. In the pro-inclusion data-set, I then use the tools of PDA to explore how these same marginalised groups use discourse to resist the discursive oppression identified in the anti-inclusion data-set, and how this discursive resistance helps those groups to advance towards positive social change.

\section{ANTI-INCLUSION DATA: CRITICAL DISCOURSE ANALYSIS}

In the analysis of the discourse of the anti-inclusion groups, I apply van Dijk's (1992) 'discursive strategies of denial' framework. Van Dijk's framework was devised from the analysis of data in which expressions of racism were identifiable in the discourse. In Van Dijk's data, as in my own data-set, disclaimers and denials were used frequently as a way of legitimating the expression of racist and, in my case, homophobic viewpoints. Van Dijk (1992, p. 94) rightly observes that people 'deny, mitigate, justify or excuse negative acts towards minorities in order to emphasize their compliance with the law or with norms and to stress their role as competent, decent citizens.' Van Dijk proposes a number of denial strategies which have the overriding face-saving function of creating positive self-representation on behalf of the speaker/s. Such strategies are used in the knowledge that it is socially (and legally) unacceptable to publicly express racist views - the same applies to the expression of homophobic views. All of the denial strategies identified by Van Dijk are found in the data analysed for this project. Again, in what follows, a brief explanation of each denial strategy will be provided accompanied by illustrative examples from the data.

The first denial strategy identified by Van Dijk is that of disclaimer. In the data for this research, this strategy would be typified as having the meaning of 'I'm not homophobic but...' and refers to instances where the speaker uses the disclaimer to save face but then follows the disclaimer move with a negative assertion, as in the third example from those presented below: 
we don't discriminate against the LGBT community

we would not impose our morals on you you do not impose your morals on us

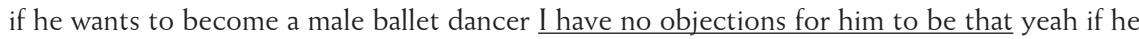
wants to dress in a skirt okay and put his little frock on and dance around in front of his male partner we have no issue with that

The disclaimers have the intended effect of rendering the speaker incapable of expressing any sort of homophobic view - in turn, this legitimises the actual argument that is presented. Note how the speaker in the third example intersperses the underlined disclaimers with stereotypical remarks which are homophobic.

Another denial identified by Van Dijk's is reverse charge. This is where the speaker who is making a prejudicial comment claims that the target of their comment are the ones who are prejudiced whilst the speaker themselves is not. Reverse charge denials are often typified by accusations against the target groups of oversensitivity, intolerance and preventing free speech. The typical meaning expressed in a reverse charge denial is 'They're the ones who are discriminating against us...'. In the data, the reverse charges focus predominantly on accusing the pro-inclusion groups as being intolerant, mainly of Islam. Some illustrative examples include:

parents are feeling that the LGBT community has become intolerant towards them and their religious belief

we were asking don't force your morals on us that's extremism that's totalitarian attitude

schools it seems have very surreptitiously been teaching LGBT values over many years [...] they were basically proselytising homosexuality to children

you're arguing for your legal rights but you're painted as some kind of aggressor you know who's trying to change the system in some kind of insidious way

there are paedophiles in there this is a paedophilia agenda

In these examples the charges directed at the LGBT community are that they are intolerant (particularly towards Islam), extremists, devious, and paedophiles. In other words, the views expressed towards the pro-inclusion groups are harsh and inflammatory in that they present their actions as illegal under British law, thus reinforcing a criminalisation discourse in relation to homosexuality. A further dimension of the reverse charge examples is that they sometimes contain metaphors. The metaphorical reverse charges function to enhance perceptions of the 'threat' being conveyed (in this case, the perceived 'threat' of LGBT+ inclusion in RSE). Examples include: 


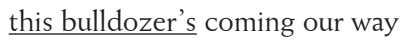

it's going to kind of like crush our kids under the LGBT banner

your values and your morals are just gonna be trampled over

These metaphors focus on the idea of 'heaviness' and 'weight' and 'being crushed' by progressive moves towards LGBT + equality in the school curriculum. The effect is that the anti-inclusion groups are presented as if they are marginalised and do not have a voice - the reality, of course, is that they are simply expressing dominant ideologies about the presumed normativity of heterosexuality which have been around for centuries. However, the repeated use of these metaphors disguises that dominant ideological position and, again, charge the pro-inclusion groups with being the 'aggressors'.

Another strategy is transfer in which the speaker uses language in a way which transfers the attitudes being expressed to some unnamed 'other' rather than to themselves. The typical meaning of transfer denials is 'I've got nothing against them but other people might be offended, threatened etc...'. In the data, transfer denials were often used in ways which transferred the homophobic attitudes being expressed to an unnamed 'community' and to unspecified 'parents' and 'children'. Some examples are:

this community is a religious community

the community's ethos the community has a faith-based ethos then the school should reflect that

this is the kind of material that's absolutely horrific for a five year old seven year old

In all of these examples, the implied meaning is that the generalised groups specified will suffer as a result of the values and actions of the pro-inclusion groups.

The next denial strategy in Van Dijk's framework is defence with the typical meaning of 'I didn't intend it that way...' . Defence strategies typically presuppose accusations with the speaker denying that they have engaged in any sort of negative act - the defence itself may be pre-emptive and arguing that the perceived homophobia was unintentional is a strategy used frequently by the speakers in the data-set. As Van Dijk observes, this is a very effective strategy as the accuser has few ways of actually proving intention. Some defence examples in the data are: 
I didn't say that I was going to ignore the fact

there has been a lot of misinformation in the media

they were completely false allegations

that whole piece for example was framed in a way of the Muslim kind of other trying to take over a peaceful school or a peaceful society

The above examples show that the main form of defence used by the anti-inclusion groups is based around accusations of inaccurate and misleading media reporting.

The mitigation denial strategy functions to minimise the level of prejudice (homophobia) being expressed or referred to. The typical meaning of mitigation is 'I did not threaten him, but gave friendly advice.' An example from the data is:

when the gay pride march is taking place it will also be a peaceful protest

Van Dijk notes that mitigation strategies are often used in situations where social norms are strong - in the case of gay pride marches, there is a strong taboo against homophobia and a social norm which is opposed to any kind of protest or discrimination (especially as, historically, gay pride marches are themselves protest marches against homophobia).

The justification denial strategy is defined by Van Dijk as linguistic items which function to legitimate the prejudicial viewpoint being expressed. The typical meaning of justification denial strategies is 'We have a right to know' and typically appeals to the perceived 'rights' of the speaker to express themselves freely. Some examples from the data-set include:

I have a right to speak up as a British citizen

I'm the parent I know my child I know what my child is capable of why would a school's opinion be more than mine

the Education Act 1944 says very clearly that pupil pupils are to be educated in accordance with their parents' wishes right now this is enshrined in British law and in primary legislation

The examples above show that appealing to speaker's 'rights' (as a parent and as a British citizen) is a key means in which the speakers justify their negative views of pro-inclusion. In these examples, the speakers claim that they have a right to express their opinion as a legitimate defence against any opposition which may emerge to the (discriminatory) views they espouse. 
A denial strategy used occasionally in the data-set is what Van Dijk terms excused, referring to linguistic expressions which excuse the prejudicial attitude or behaviour in some way. Excused examples may involve the speaker putting blame on a set of special circumstances which relate to the view being expressed, such as a desire not to aggravate tensions. The excused category is used in the data-set mainly in a way which legitimises the homophobia on the grounds of children's 'innocence' in relation to issues of gender and sexuality identity.

children are very innocent

they're not ready for all these things that we put on them yet we don't wanna take the childhood away we don't wanna take their innocence away we just want them to be children

These instances occur despite the fact that it is well-documented that heterosexuality is widely and very visibly represented and rigorously promoted throughout all aspects of the school curriculum. These examples overlap with the transfer strategy which positions children as in need of protection from knowledge about sexuality. Again, the implicit assumption is that knowledge about same-sex relationships is considered dangerous and a threat to 'innocence' whereas knowledge about heterosexual identities and relationships is benign and has a preservation function in relation to childhood innocence. In other words, homosexuals are a threat to children whilst heterosexuals are their saviours and guardians. This fallacy is reiterated numerous times throughout the data-set.

The final category in Van Dijk's framework is provocation (or victim-blaming) in which the speaker claims that the target of their prejudice did something to provoke the negative attitude towards them being expressed. This strategy overlaps somewhat with the reverse charge denial strategy and functions as a justification for holding harshly negative views - in this case, against pro-inclusion communities. Some examples include:

where this is this issue has arisen from is the lack of transparency of Sarah Hewitt Clarkson ${ }^{4}$ a lack of her responsibility to consult people who hold their religious faith very close to their heart

we simply don't want you teaching our children that it's okay to be gay that that is proselytising our children you over the period of the primary schooling you're changing the children's view you or you're influencing it for them to believe that this is normal it's acceptable and and that's just not right

4. Headteacher at one of the Birmingham primary schools where the protests took place. 
you are just being arrogant to show whoever it is that you can run the school on your own and be added on and run it the way you want

why do you wanna groom them why do you wanna promote them it's like promoting them brainwashing them

The specific provocations claimed in the above examples (which occur frequently throughout the data) focus mainly on teaching staff not consulting with parents (at the time of the protests, the individual school programmes for RSE teaching will already have received approval from the school governing bodies) and on 'grooming' and 'proselytising' children. However, the groups provide no indication of what they believe the children are being groomed for when teaching about the existence of LGBT+ identities and relationships. The unspoken assumption in these examples is that homosexuality is associated with paedophilia - an outdated and inaccurate ideology which functions to promote a negative and criminalising discourse around homosexuality.

Table 1 shows the relative distribution of discursive strategies of denial (by percentage of total occurrences as well as numbers of occurrences of each strategy) across the whole data-set.

Table 1. Discursive strategies of denial - Patterns of use

\begin{tabular}{|l|l|l|}
\hline Discursive strategy of denial & $\begin{array}{l}\text { Total number of occurrences in } \\
\text { data-set }(\mathrm{n})\end{array}$ & $\begin{array}{l}\text { Percentage of total occurrences } \\
\text { of denial strategies across data- } \\
\text { set }\end{array}$ \\
\hline Disclaimer & 25 & 13.3 \\
\hline Reverse charge & 69 & 36.7 \\
\hline Transfer & 15 & 8 \\
\hline Defence & 26 & 13.8 \\
\hline Mitigation & 4 & 2.1 \\
\hline Justification & 22 & 11.7 \\
\hline Excused & 9 & 4.8 \\
\hline Provocation & 18 & 9.6 \\
\hline
\end{tabular}

Table 1 shows that the most frequently used discursive strategy of denial is the reverse charge strategy. Reverse charge instances function to deflect attention away from the beliefs and actions of the anti-inclusion groups themselves and instead target accusations against the pro-inclusion groups. The accusations are inflammatory and often imply illegal behaviour on the part of the pro-inclusion groups - extremism, white supremacy, paedophilia and an abuse of power by 
headteachers who implement inclusion-based teaching. This has a discursive effect of 're-criminalising' LGBT + populations and those who are supportive of their rights. The pro-inclusion groups are the ones who are cast as undemocratic and as flouting the constitutional rights (including rights to equality) of the protesters. Disclaimers and defence discursive strategies are also used with a relatively high frequency in the data. The disclaimers work to pre-empt accusations of homophobia which the anti-inclusion groups know is socially unacceptable. The reverse charge and disclaimer strategies work together to construct a positive self-representation of the protesters - they are both non-homophobic and also the defenders of British democratic values and constitutional rights. This, again, echoes Van Dijk's findings in relation to discourses of racism:

[the] strategic play of denial and reversal at the same time involves the construction of social roles [...] such as allies and enemies, victims, heroes and oppressors. In many respects, such discourse mimics the discourse of anti-racists by simply reverting the major roles: victims become oppressors, those who are in power become victims. (VAN DIJK, 1992, p. 105)

The defence strategies then provide the anti-inclusion groups with a further layer of face-saving and protection against accusations of homophobia - these strategies focus on false reporting and misrepresentation. As a final face-saving act, the antiinclusion groups can claim that they simply did not do or say anything homophobic or, if they did, can claim that it was not intended as such.

The results from the applications of Van Dijk's CDA frameworks show that the anti-inclusion groups are highly skilled in deploying a range of discursive strategies of prejudice and denial of homophobia. The overall use of these strategies enables the anti-inclusion groups to legitimately express homophobic views in a way which preserves their positive self-image (as upholders of democracy and marginalised 'victims') and facilitates expression of homophobic views in a societal context which condemns homophobia and other forms of discrimination. It is unsurprising, therefore, that pro-inclusion groups have had to work hard to resist the discourses propounded by the anti-inclusion groups. In the next section, I use elements of PDA to explore how two pro-inclusion organisations in the UK have succeeded in creating resistant discourses.

\section{PRO-INCLUSION DATA: POSITIVE DISCOURSE ANALYSIS}

Whilst a number of possibilities for applying PDA have been proposed, the PDA in this article focuses predominantly on the feature of 'discursive re-framings' 
and draws on approaches to analysing re-framings proposed by Macgilchrist (2007) and Nartey and Ernanda (2020). This is mainly because discursive re-framings appeared to be the most predominant strategy used in the texts as a means of resisting dominant discourses and effecting social change and emancipation for LGBT + people. Furthermore, the re-framings in the Imaan LGBTQ and Schools Out texts respond directly to the views expressed by the protesters discussed in data-set 1. Macgilchrist defines discursive re-framing as follows:

Reframing can be defined as shifting an issue away from its conventional 'location' within one set of shared assumptions and reconstruing it within a different set of knowledges. In this way the issue is assigned a different interpretation, i.e. comes to have a different 'meaning' in its new context. (MACGILCHRIST, 2007, p. 80)

In their PDA of a political speech given by Sukarno, the first president of Indonesia, Nartey and Ernanda (2020) suggest a number of specific discursive strategies of re-framing which I consider in this section: an implied 'us' vs. 'them' dichotomy; the use of metaphorical framing; contrastive argumentation; and parallelism. Again, these strategies were identified in the data analysed for this study as a means of resisting dominant discourses and moving towards emancipation and positive social change (although metaphorical framing was used rarely and will not therefore be included in the analysis that follows).

The first of these strategies - the 'us' vs 'them' dichotomy - involves the discursive use of 'othering' and the implied construction of an in-group (whose values are aligned with those of the author) and an out-group whose implied values are more ideologically and socially dominant than those of the in-group. In the data, an implied 'us' or 'in-group' was constructed in the Imaan LGBTQ texts as those who are knowledgeable about what the Quran has to say about gender and sexuality. This was set against the 'them' out-group construed as those lacking in such knowledge and who uncritically accept popular myths and misinterpretations of Quranic scripture. This is an effective strategy because it undermines many of the claims made by the protest groups concerning their religious beliefs about sexuality being disregarded. Imaan LGBTQ essentially state that the claims of the anti-inclusion groups are wrong and that they are misinformed about Islamic beliefs and Quranic scripture. Furthermore, the anti-inclusion groups are deliberately misinterpreting the text (creating 'myths' and 'stories') in order to promote their own homophobic ideology. This is stated explicitly early on in the Imaan LGBTQ text:

As with every other culture, Muslim cultures throughout the world have negative stereotypes of LGBT people, and have created myths and stories that have served only to alienate and 
hurt LGBT people. You probably have many questions, many of which stem from the myths and stories you may have heard

Thus, the resistance works not only by identifying the anti-inclusion groups as homophobes but as positioning 'them' as unknowledgeable about the Quran. Lack of knowledge is also a key construct of the 'them' group in the Schools Out data in which unspecified 'people' are sometimes constructed as an out-group who lack sufficient knowledge about RSE, as in the following example:

People often only hear the word sex and they need to remember that education is about relationships too.

Other examples focus on aligning the writer ('us') with 'the state' with gives their arguments governmental authority and legitimation. These examples cast the outgroup as opposing national (British) values which runs in direct contradiction to the way the protest groups themselves attempt to cast the pro-inclusion groups as un-British and undemocratic (the 'us' and 'them' groups are highlighted in the examples below):

Thankfully our country [us] has moved on from the institutionalised bigotry [them] of the past.

Recently, we [us] have seen very conservative Jewish, Christian and Muslim schools [them] attempting to avoid teaching children about evolution or attempting to present creationism in science lessons as an acceptable account of human origins. The state [us] quite rightly takes severe action against such attempts.

The state's [us] requirement for this to be taught to all primary school children however outrages some very conservative Jewish, Christian, or Muslim parents. They [them] consider such teaching incompatible with their religious belief that homosexual or lesbian relations are a major sin.

Interestingly, the use of 'the state' in the final two examples to align with the values of the in-group functions to de-personalise the assertions being made - this strategy also references institutional authority as an attempt to empower the in-group.

Another discursive strategy explored by Nartey and Ernanda is that of contrastive argumentation in which the writer acknowledges an argument or world-view presented by the 'other' but then counters it with their own. Nartey and Ernanda refer to this specific type of contrastive argumentation as a concession-refutation in that the strategy is often realised in texts by these patterns of semantic moves. This strategy is similar to what Macgilchrist (2007) defines as 'radical reframing' and can be seen in the examples below: 
you may feel that your child has died, and you may go through a grieving process with the accompanying emotions of shock, denial, disbelief, guilt, anger, a sense of loss, and disappointment. [Concession] You have not lost your child, what you have lost is the perception you had of your child. [Refutation]

While it may be far-fetched to equate this with direct references to male homosexuality [Concession], as Quranic text it should be taken into account in any interpretations that serve to condemn homosexuality without question. [Refutation]

traditional Islamic views have condemned homosexuality without much thought. [Concession] However, the analysis at the top of the page has showed how the Quran may well not condemn homosexual love. Taking this into account, the principles of love, companionship and comfort in marriage may be applied to Muslim gays and lesbians [Refutation]

All free societies recognise that parents have the right to raise children in accordance with the parents' religious beliefs and values. Denying that would vitiate freedom of religion or belief. [Concession] However, all children also have fundamental human rights, which the state must protect, even against the wishes of their parents. [Refutation]

The Imaan LGBTQ texts make use of a slightly different form of contrastive argumentation - that of antithesis in which two contrasting views are presented side by side. In the case of antithesis, there is no concession of the first view presented - it is dismissed or directly opposed in the second semantic move. The question/statement and answer/response sequences at the beginning of the Imaan LGBTQ text are typical examples of this discursive strategy. This can be seen in the following examples which present antithetical views concerning Islamic beliefs about homosexuality. In each case, the second part (in italics) presents an antithetical argument to the first part.

Q: What does the Quran say about homosexuality: Isn't it a sin?

A: The Quran says little about homosexuality and many claims are made about the content of the Quran that do not necessarily stand scrutiny.

Our religion says that homosexuality is a sin

Muslim religious leaders bave joined Christian and Jewish leaders in issuing a joint plea for tolerance for LGBT people.

Homosexuality is a Western phenomena

LGBT people represent every socio-economic, ethnic and religious background possible, and live in every country of the world.

Is homosexuality an illness?

Homosexuality is not an illness or a disability and should not be classed as one. It is a statement of love between two people of the same gender. The World Health Organisation states 'Sexual orientation is not to be regarded as a disorder'.

Is there a cure for homosexuality?

Homosexuality is not a disease or disorder, so there is notbing to cure. 
Once my child is married s/he will be happy

Marriage can be destructive for your child, and lead to further isolation. If you force your child to get married not only will you be ruining bis/ber life but that of their spouse.

In these examples, the Imaan LGBTQ text is highly effective at undermining many of the disclaimers, justifications and defences used by the protest groups in putting forward their position against LGBT + inclusion. And the use of antithesis calls into question the truth value of the claims made by the anti-inclusion groups.

In their data, Nartey and Ernanda identify a further discursive strategy of parallelism which is closely related to antithesis. Parallelism, however, refers more to the rhetorical issue of parallel structures in discourse and tends to be more explicitly emotive than antithesis. The rhetorical effects of parallelism include the reinforcement of key themes and ideas, reiteration and emphasis. In the political speech data analysed by Nartey and Ernanda, these effects are often evidenced through spontaneous applause - clearly this is not evident in the written texts analysed in this article. However, there do appear to be some examples in both the Imaan LGBTQ and Schools Out pro-inclusion data which make use of parallel discourse structures for rhetorical effect which appeals to the emotions of the reader.

By labelling LGBT people as sick or as sinners reinforces society's homophobia and encourages violence towards LGBT people. Would you want your child to be treated this way?

No disease can be considered a punishment from Allah. Regardless of whether you are black, white, or any other colour, whether you are LGBT, straight, rich or poor, whether you live anywhere in the world, HIV has a potential to infect anyone.

sexual harassment and sexual abuse in Hollywood, the White House, the Senate, the House of Commons and the British theatre are making the headlines. Meanwhile we are becoming aware of an upsurge in sexual harassment and abuse in schools. We believe the two are related.

By using books that utilise LGBT + people we are doing exactly the same as ensuring all the books we use do not solely represent white people.

all children also have fundamental human rights, which the state must protect, even against the wishes of their parents. For example, parents are normally free to take medical decisions on behalf of their children. However, the UK government will mandate a blood transfusion for a child even if the parents, for example in the case of Jehovah's Witnesses, believe a blood transfusion to be religiously prohibited.

Taken together, the positive discourse strategies used by the two pro-inclusion groups in the texts analysed function as the kind of discursive 're-framings' identified by Macgilchrist (2007) and also as the kind of 'counter-narratives' identified by PDA writers such as Martin (2004), Hughes (2018) and Rogers and Mosley 
Wetzel (2013). Rogers and Mosley Wetzel assert that such counter-narratives are intentionally orchestrated and organized in opposition to the dominant ideologies and worldviews and, therefore, function effectively as a locus of analysis in PDA. Counter-narrative re-framing appears to be effective in the pro-inclusion data as the strategy undermines the bases of the reverse charges used by the anti-inclusion groups as a key means of supporting their arguments.

\section{CONCLUDING REMARKS}

The combined CDA and PDA analysis in this article has shown firstly that the anti-inclusion groups use a number of discursive denial strategies in order to legitimately express a viewpoint which marginalises and delegitimises LGBT+ identities. Furthermore, these groups create a discourse which aims to construct LGBT + communities themselves as undemocratic and discriminatory. The most frequent discursive strategy used by the anti-inclusion groups to achieve this effect is that of the reverse charge, although the strategies of disclaimer and defence are also relatively common. These strategies function to move the focus away from the behaviour of the protest groups themselves and encourage greater scrutiny of those supporting LGBT inclusion in the RSE guidance. By contrast, the proinclusion groups predominantly use a discursive strategy of 're-framing' in order to enact resistance to the ideologies constructed by the protest groups. In doing so, the re-framing works as a strategy which deconstructs the arguments underpinning the reverse charges (and those of other discursive strategies) deployed by the anti-inclusion groups. Re-framing therefore emerges from the PDA as a potentially powerful discursive strategy of resistance which enables pro-inclusion groups to progress their position and move towards social change.

Moreover, conflicting discourses of 'democracy' and 'equality' emerge from analysis of the data with both groups claiming that the other is undemocratic and non-compliant with UK equality laws. In the UK, democratic values are enshrined in law, such as the Equality Act. And both groups have a legal right to equitable treatment under this act in relation to the 'protected characteristics' of religion, gender identity and sexual orientation. The rhetoric of the anti-inclusion groups focuses around claims that equality law is not being upheld, and therefore democratic values are being undermined through the inclusion of LGBT + content in the school curriculum. But the pro-inclusion groups counter this by refuting the religious basis of the claims that the anti-inclusion groups are building their arguments around. The very concepts of equality and democracy are therefore 
highlighted as being particularly fragile and unstable at intersections of particular kinds of sexual diversity and religious diversity and in specific contexts. PDA shows that pro-inclusion groups are doing important work at addressing these instabilities in ways which reconcile different types of diversity and which promote productive dialogue around the issues. The ultimate aim of the pro-inclusion texts is to move towards positive social change. Therefore, although this article focuses specifically on resistant discourse in relation to homophobia, the findings could perhaps be used as a starting point for exploring resistance in relation to other types of discriminatory discourse.

\section{REFERENCES}

BARTLETT, T. (2012). Hybrid Voices and Collaborative Change: Contextualising Positive Discourse Analysis. London: Routledge.

FLOWERDEW, J. (2008). Critical discourse analysis and strategies of resistance. In: Bhatia, V., Flowerdew, J. and Jones, R. (eds.) Advances in Discourse Studies. London: Routledge, p. 195-210.

HUGHES, J. (2018). Progressing Positive Discourse Analysis and/in Critical Discourse Studies: Reconstructing resistance through progressive discourse analysis. Review of Communication. 18, 3, p. 193-211.

JACKSON, J. (2014). Introducing Language and Intercultural Communication. London: Routledge.

LUKE, A. (2002). Beyond science and ideology critique: Developments in critical discourse analysis. Anmual Review of Applied Linguistics. 22, p. 96-110.

MACGILCHRIST, F. (2007). Positive discourse analysis: Contesting dominant discourses by reframing the issues. Critical Approaches to Discourse Analysis Across Disciplines. 1, 1, p. 74-94.

MARLOW, M. (2015). The American Dream? Anti-immigrant discourse bubbling up from the Coca-Cola 'It's Beautiful' advertisement. Discourse and Communication. 9, 6, p. 625-641.

MARTIN, J.R. (2004). Positive discourse analysis: Solidarity and change. Revista Canaria de Estudios Ingleses. 49, p. 179-202.

MARTIN, J.R. (1999). Grace: The logogenesis of freedom. Discourse Studies. 1, 1, p. 29-56. 
NARTEY, M.; ERNANDA (2020). Formulating emancipatory discourses and reconstructing resistance: a positive discourse analysis of Sukarno's speech at the first Afro-Asian conference. Critical Discourse Studies. 17, 1, p. 22-38.

ROGERS, R.; MOSLEY WETZEL, M. (2013). Studying agency in literacy teacher education: A layered approach to positive discourse analysis. Critical Inquiry in Language Studies. 10, 1, p. 62-92.

SAUNTSON, H. (2018). Language, Sexuality and Education. Cambridge: Cambridge University Press.

SAUNTSON, H. and Borba, R. (In press) Silence and sexuality in school settings: A transnational perspective. In J. Stern, M. Walejko, C. Sink and W. Ping Ho (eds) The Bloomsbury Handbook of Solitude, Silence and Loneliness. London: Bloomsbury.

STIBBE, A. (2017). Positive discourse analysis: Re-thinking human ecological relationships. In: Fill, A. and Penz, H. (eds.) The Routledge Handbook of Ecolinguistics. London: Routledge.

VAN DIJK, T. (2006). Discourse and manipulation. Discourse and Society. 17, 3, p. 359-383.

VAN DIJK, T. (2001). Multidisciplinary CDA: A plea for diversity. In: Wodak, R. and Meyer, M. (eds) Methods of Critical Discourse Analysis. London: Sage, p. 95-120.

VAN DIJK, T. (1992). Discourse and the denial of racism. Discourse and Society. 3, 1, p. 87-118.

WODAK, R.; MEYER, M. (eds) (2009). Methods of Critical Discourse Analysis (2nd edition). London: Sage.

Recebido: 28/8/2020

Aceito: $24 / 11 / 2020$

Publicado: 25/11/2020 